\title{
Anthropometric study of some craniofacial parameters: head circumference, nasal height, nasal width and nasal index of adult Omoku indigenes of Nigeria
}

\author{
${ }^{1 *}$ Oladipo, G. S., ${ }^{2}$ Okoh, P.D., ${ }^{1}$ Akande, P.A., ${ }^{1}$ Oyakhire, M.O. \\ ${ }^{1}$ Department of Human Anatomy, Faculty of Basic Medical Sciences, \\ College of Health Sciences, University of Port Harcourt. \\ ${ }^{2}$ Department of Surgery, College of Health Sciences, \\ University of Port Harcourt Teaching Hospital, Port Harcourt-Nigeria \\ E-mail: oladipogabriel@yahoo.com
}

\begin{abstract}
The aim of this study is to document the mean head circumference; nasal height; nasal width and nasal index of adult Omoku from Ogba/ Egbema/ Ndoni Local Government Area of Rivers State, Nigeria and to provide a comprehensive data for use by anthropologists and medical practitioners. Craniofacial anthropometry is vital in making a precise and systematic measurement of human skull. A total of eight hundred (800) adults comprising 400 males and 400 females with age ranging from 18 years and above were used for this study. All the subjects were drawn from Omoku ethnic group in Rivers State. The results showed that the omoku male and female had mean head circumference of $55.72 \mathrm{~cm}$ and $54.89 \mathrm{~cm}$ respectively, mean nasal height of $4.66 \mathrm{~cm}$ and $4.36 \mathrm{~cm}$ respectively, mean nasal width of $4.01 \mathrm{~cm}$ and $3.93 \mathrm{~cm}$ respectively and mean nasal indices of 86.09 and 90.16 respectively. The z-test analysis indicates a sexual dimorphism, with significantly higher values of all the parameters in males compared to the females $(p<0.05)$. This study is therefore recommended to forensic anthropologists, craniofacial surgeons and medical practitioners and also serves as the basis for future studies on other Nigerian ethnic group.
\end{abstract}

Keywords: Head circumference, nasal height, nasal width, nasal index, anthropology

\section{INTRODUCTION}

Anthropometry is concerned with measurement of physical sizes and shapes of human body. Craniofacial anthropometry is an integral part of craniofacial surgery and syndromology. It is a technique used in both physical and clinical anthropology comprising precise and systematic measurements of the bones of the human skull.

Craniofacial anthropometry also includes nasal height, nasal width, and nasal index. It is very important for the study of human growth and variation in different races and also for clinical diagnosis and treatment (Poswillo, 1963).

Oladipo et al., (2009c) reported that the nasal index of male Andonis and okrikas were 79.83 and 86.23 respectively and female Andonis and Okrikas were 83.77 and 86.46 respectively. Another study was carried out by Franciscus and Long, 1991 in Onges. They reported that the mean nasal index for males fell between the ranges of $77.3-97.7$ while those of females fell between the ranges of 70.5-97.4.

Oladipo et al., (2010) also reported the mean head circumference and mean nasal height of $53.60 \mathrm{~cm}$ and $3.99 \mathrm{~cm}$ respectively for ljaw male children while those of female children were $53.00 \mathrm{~cm}$ and $3.88 \mathrm{~cm}$ respectively.

The aim of this study is to document the mean head circumference; nasal height; nasal width and nasal index of adult ljaws of Bayelsa state of Nigeria which could be of importance in clinical practice, forensic anthropology, genetics and paleoanthropological studies.

\section{MATERIALS AND METHODS}

The present study was carried out in Ogba/Egbema/ Ndoni Local Government Areas in Rivers State of Nigeria. This study was carried out on adult Omoku who were selected at random from the above named 
communities. A total of eight hundred (800) adults (18 years and above) comprising four hundred (400) males and four hundred (400) females were.

Subjects with craniofacial defects were not used. A non- stretchable tape was used for the measurement of head circumference while a sliding caliper for the measurement of nasal height and nasal width. The subject was seated comfortably on a chair with his/her head at the same level as the examiner's head. The subject's was well illuminated. The head circumference (distance between the glabella and occipital protuberance); was then determined by having the subject look straight at the examiner while the tape was used to wrap around the occiput to the anterior portion of the skull.

The nasal height was measured as the distance between the nasion to nasopinale of the nose. Nasal width was measure as the distance between the two alar. The subjects were instructed to look forward while the sliding caliper was placed on the nose of the subject; then scroll until it is tightly fixed on the subject's nose. Measurement was then taken with an accuracy of $0.01 \mathrm{~cm}$; the nasal index was then calculated as nasal width distance /nasal height distance $\times 100$. Statistical analysis was made with Ztest at significance level of 0.05

\section{RESULTS}

The results of this study were presented inTables1-5. The mean values of the craniofacial parameters investigated were compared statistically using z-test. The results obtained indicated a sexual dimorphism with significantly higher values of all the parameters in males compared to corresponding females $(p<0.05)$.

The mean head circumference for males and females were $55.72 \mathrm{~cm}$ and $54.89 \mathrm{~cm}$ respectively (Table1). The mean nasal height for males and females were 4.66 and $4.36 \mathrm{~cm}$ respectively (Table2). The mean nasal width for males and females were 4.01 and $3.93 \mathrm{~cm}$ respectively (Table 3 ). The mean nasal index for males and females were 86.09 and 90.16 respectively (Table 4). The result of the Z-test is shown in table 5 while table 6 shows the comparative data on other various populations.

Table1: Result of Head circumference of adult Omoku

\begin{tabular}{|llclll|}
\hline Subject type & Sex & Mean $(\mathrm{cm})$ & STD & SEM & Sample size \\
\hline Omoku & Males & 55.72 & 2.79 & 0.14 & 400 \\
Omoku & Females & 54.89 & 2.82 & 0.14 & 400 \\
\hline
\end{tabular}

STD: Standard Deviation; SEM: Standard Error of mean

Table 2: Result on Nasal height of adult Omoku

\begin{tabular}{|llcccc|}
\hline Subject type & Sex & Mean $(\mathrm{cm})$ & STD & SEM & Sample size \\
\hline Omoku & Males & 4.66 & 0.15 & 0.02 & 400 \\
Omoku & Females & 4.36 & 0.12 & 0.02 & 400 \\
\hline
\end{tabular}

STD: Standard Deviation; SEM: Standard Error of mean

Table 3: Result on Nasal width of adult Omoku

\begin{tabular}{|llllll|}
\hline Subject type & Sex & Mean $(\mathrm{cm})$ & STD & SEM & Sample size \\
\hline Omoku & Males & 4.01 & 0.43 & 0.02 & 400 \\
Omoku & Females & 3.73 & 0.38 & 0.02 & 400 \\
\hline
\end{tabular}

STD: Standard Deviation; SEM: Standard Error of mean

Table 4: Result on Nasal index of adult Omoku

\begin{tabular}{|llllll|}
\hline Subject type & Sex & Mean $(\mathrm{cm})$ & STD & SEM & Sample size \\
\hline Omoku & Males & 86.09 & 9.60 & 0.59 & 400 \\
Omoku & Females & 90.16 & 9.20 & 0.70 & 400 \\
\hline
\end{tabular}

STD: Standard Deviation; SEM: Standard Error of mean 
Table 5: Results of significance test between males and females Omoku indigenes

\begin{tabular}{|c|c|c|c|c|c|}
\hline Parameters & Comparison & Z-critical & $\begin{array}{l}\text { Z- } \\
\text { calculate } \\
\text { d }\end{array}$ & $\begin{array}{l}\text { Level of } \\
\text { significan } \\
\text { ce }\end{array}$ & SIGNIFICANT \\
\hline HEAD CIRCUMFERENCE & $\begin{array}{ll}\text { MALES } & \text { VS } \\
\text { FEMALES } & \end{array}$ & 1.96 & 4.24 & $P<0.05$ & SIGNIFICANT \\
\hline BRIDGE HEIGHT & $\begin{array}{ll}\text { MALES } & \text { Vs } \\
\text { FEMALES } & \end{array}$ & 1.96 & 3.22 & $P<0.05$ & SIGNIFICANT \\
\hline NASAL WIDTH & $\begin{array}{ll}\text { MALES } & \text { Vs } \\
\text { FEMALES } & \\
\end{array}$ & 1.96 & 3.96 & $P<0.05$ & SIGNIFICANT \\
\hline NASAL INDEX & $\begin{array}{ll}\text { MALES } & \text { Vs } \\
\text { FEMALES } & \\
\end{array}$ & 1.96 & 2.13 & $P<0.05$ & SIGNIFICANT \\
\hline
\end{tabular}

Table 6: Comparison of Head circumference, Nasal height, Nasal width, Nasal index of Omoku indigenes with other population

\begin{tabular}{|l|l|l|l|l|l|}
\hline Author/year & Population & HC $(\mathrm{cm})$ & NH $(\mathrm{cm})$ & NW $(\mathrm{cm})$ & N.I \\
\hline Ozturk et al.,(2006) & Turkish & $58.0(\mathrm{~m})$ 55.9(f) & $4.7(\mathrm{~m})$ 4.2(f) & - & - \\
\hline Oladipo et al.,(2007) & Nigerian Ogonis & - & $3.99(\mathrm{~m}) 3.91(\mathrm{f})$ & - & - \\
\hline Oladipo et al., (2008a) & Nigerian ljaws & - & $4.71(\mathrm{~m}) 4.43(\mathrm{f})$ & - & - \\
\hline Oladipo et al., 2009b & Nigerian Yorubas & - & - & - & $90.02(\mathrm{~m}) 83.58(\mathrm{f})$ \\
\hline Present study & Nigerian Omoku & $55.72(\mathrm{~m}) 54.89(\mathrm{f})$ & $4.66(\mathrm{~m}) 3.36(\mathrm{f})$ & $4.01(\mathrm{~m}) 3.93(\mathrm{f})$ & $86.09(\mathrm{~m}) 90.16(\mathrm{f})$ \\
\hline
\end{tabular}

NOTE: $\mathrm{HC}=$ Head circumference, $\mathrm{NH}=$ nasal height, $\mathrm{NW}=$ nasal width, $\mathrm{NI}=$ nasal index, $\mathrm{m}=\mathrm{male}, \mathrm{f}=$ female

\section{DISCUSSIONS}

Craniofacial anthropometry is important in the evaluation of facial trauma, facial defect, congenital and post traumatic deformities and easy identification of certain congenital malformation and diagnosis of hypo/hypertelorism (Oladipo et al.,2008a; Oladipo et al., 2008b;Oladipo et al., 2009a).

It is necessary to have local data of these parameters since these standards reflect the potentially different pattern of craniofacial growth resulting from racial, ethic, sexual and dietary differences (Oladipo et al., 2009b)

This study shows that the mean values in males are significantly larger than those of females $(p<0.05)$. The result were in agreement with Franciscus and Long, (1991) and Oladipo et al.,(2010) who reported larger values for head circumference, nasal height, nasal width and nasal index in males than females.

Nasal index of Igbos (Oladipo et al., 2009a) is lager than that of ljaws. In conclusion, genetics and environmental factors are responsible for the variation in craniofacial dimension between and within populations (Cem et al., 2001; Kasai et al., 1993).
The result of this study will be of immense use in forensic medicine and anthropology and will also serve as a future framework for estimating the craniofacial dimensions of other Nigerians ethnic groups.

\section{REFERENCES}

Cem E., Cengiz Y., Hamdi E., Selim D., Yasar D.,( 2001):Normative values of craniofacial measurements in idiopathic benign microcephalic children. The cleft palate. Craniofacial Journals. 38(3):260-263.

Franciscus R.G., and Long J.C., (1991):Variation in human nasal height and breadth. Am J. Physical Anthropology.85: 419-42.

Kasai, K., Richards L.C., Brown, T., (1993): Comparative study of Craniofacial Morphology in Japanese and Australian Aboriginal Populations. Human Biol. 65: 821-834.

Oladipo G.S., Olotu J.E., Didia B.C., (2007):Anthropometric study of nasal parameters of the Ogonis in Nigeria. Scientia Africana.6(1): 69-71

Oladipo G.S., Didia B.C., Okoh P.D., Hart J.S.,(2008a): Sexual dimorphism in facial dimensions of adults ljaw. J. Expt and Clin. Anat.7(2):10-14. 
Oladipo G.S., Olotu E., Guinireama I.U., (2008b):Anthropometric comparision of canthal indices between the ljaw and Igbo tribes. Scientia Africana $7(1): 141-144$.

Oladipo G.S., Fawehinmi H.B., Okoh P.D., (2009a):Canthal indices of Urhobo and Itsekiri eyhnic groups. Australian Journal of Basic and Applied Sciences. 3(4):3093-3096.

Oladipo G.S., Fawehinmi H.B., Suleiman Y. A., (2009b):The study of nasal parameters (nasal height, width and nasal index) among the Yorubas of Nigeria. The Internet Journal of Biological Anthropology. 3(2):119.
Oladipo G.S., Eroje M.A., Fawehinmi H.B., (2009c):Anthropometric comparison of the nasal indices between the Andoni and Okrika ethnic groups of Rivers State, Nigeria. International Journal of Medicine and Medical Sciences. 1(4): 135-137.

Oladipo G.S., Chinagorom E., Iruoghene G.O.,(2010):Craniofacial dimension of ljaw children of Nigeria. Biomedicine International. 1(2):25-29.

Ozturk F., Yavas G., Inan U.U., (2006): Normal periocular and anthropometric measurements in Turkish population. Ophthalmic Epidemiol. 13 (2): 14-19.

Poswillo D.,(1963): Causal Mechanism for Craniofacial Deformity. Journal of Tropical Pediatrics. 44: 973-977. 